and D. George (eds.)

\title{
Replacement of adult maxillary jaws in Eunicida (Polychaeta)
}

\author{
HANNELORE PAXTON \\ Department of Biological Sciences, Macquarie University, Sydney, N.S.W. 2109, Australia. \\ E-mail: hpaxton@rna.bio.mq.edu.au
}

\begin{abstract}
SUMMARY: Replacement of adult maxillary jaws is reported for Diopatra aciculata. The process is similar to arthropod moulting, commencing with apolysis or retraction of the epidermal cells from the inner surface of the old cuticle, followed by formation of the new cuticle. This results in the jaw-in-jaw or pharate state. Ecdysis or shedding of the old cuticle takes place without any splitting or damage as evidenced by complete, fully articulated shed jaws found in the gut. Newly moulted maxillae are soft and white until they become sclerotized. The new jaws are about 1.4 times the size of the old ones (moult increment). The same process is expected to occur in all extinct and extant Labidognatha. The Recent Lumbrineridae maxillae may not be of the labidognath type, but probably moult in the same manner. Occasional finds of pharate jaws of the extinct Placognatha indicate that they underwent similar jaw replacement. Not enough is known about Prionognatha, although shedding before replacement may occur. Jaw replacement in Ctenognatha, where the new elements form in sac-like epithelial structures ventrolateral to the existing maxillae, is probably limited to this group.
\end{abstract}

Keywords: jaw moulting, jaw shedding, Diopatra aciculata, Onuphidae, Placognatha, Ctenognatha, Prionognatha, Labidognatha.

RESUMEN: El REEMPLAZO DE MANDíBULAS EN EUNICIDA. - El presente trabajo describe el reemplazo de las mandíbulas maxilares adultas en Diopatra aciculata. Este proceso es similar a la muda en artrópodos, iniciándose con la apólisis o retracción de las células de la epidermis desde la superficie interna de la antigua cutícula, para luego formar una nueva cutícula. El resultado es la formación de una mandíbula nueva bajo la mandíbula antigua. La écdisis o muda de la vieja cutícula se lleva a cabo sin quebrantamiento o daño alguno, según se evidencia por los hallazgos de mandíbulas mudadas enteras y completamente articuladas en las vísceras. Las maxilas recién mudadas son suaves y blancas hasta que se esclerotizan. Las nuevas mandíbulas son aproximadamente 1.4 veces más grandes que las antiguas (debido a la muda). El hallazgo ocasional de este tipo de mandíbulas en el extinto grupo de los Placognatha indica que éste grupo experimentó un reemplazo similar de mandíbula. La evidencia del reemplazo de mandíbulas en el grupo Prionognatha es demasiado limitada como para sacar conclusiones. El reemplazo de mandíbula en el grupo Ctenognatha, donde los nuevos elementos se forman en estructuras en forma de saco epitelial ventrolateral a la mandíbula existente, probablemente se limita a este grupo.

Palabras clave: mudanza de mandíbula, desprendimiento de mandíbula, Diopatra aciculata, Onuphidae, Placognatha, Ctenognatha, Prionognatha, Labidognatha.

\section{INTRODUCTION}

A complex jaw apparatus consisting of ventral mandibles and dorsal maxillae is characteristic for polychaetes of the order Eunicida. The jaws are hardened cuticular structures and are composed of calcium carbonate and/or scleroproteins. While it is generally accepted that the mandibles are not shed but grow during the lifetime of the animal, there has been some controversy as to the fate of the maxillary apparatus (Paxton, 1980, 2000).

Five different types of maxillary apparatuses, based on their arrangement, number and shape of elements, have been identified within the Eunicida 
(Kielan-Jaworowska, 1966; Szaniawski, 1996; Paxton, 2000: Table 1.4). These types are not clades, but grades of evolution. Therefore, they are not clearcut taxonomic groups but include some intermediaries. Nevertheless, they are useful in considering the phylogeny of extinct and extant eunicidans. Xenognatha are known only from one species of Ordovician age. Placognatha have no modern representatives, but their jaws are frequent microfossils in early Palaeozoic deposits. They consist of posterior plates and two anterior rows of free denticles, all with large basal openings to the interior pulp cavities. Occasionally, they are found as 'jaw-within-jaw' structures that have been interpreted as jaw replacements or moulting (Mierzejewski, 1978). Ctenognatha are extinct and extant, with the living representatives being the Dorvilleidae. In addition to their posterior plates they have usually two to four rows of anterior denticles. Jaw replacement in this group is well known and has been reported for several genera, with the best documented example being Ophryotrocha labronica La Greca and Bacci, 1962 (Paxton, 2004).

Prionognatha have four to five pairs of plates in two parallel rows and long slender carriers. They are also extinct and extant, with the Oenonidae as the living representatives. Not much is known about their replacement. Kielan-Jaworowska (1966) and Colbath (1987) reported specimens with incompletely sclerotized jaws, suggesting that the old maxillae had been shed and the new ones were completing their development.

The Labidognatha have fossil and living representatives, and the best known extant families are the Eunicidae and Onuphidae. The Lumbrineridae were also considered as labidognath (Hartman, 1944; Kielan-Jaworowska, 1966), but this interpretation has been questioned (Orensanz, 1990). The Labidognatha have short carriers, four to five paired plates and one unpaired plate. The anterior plates form a semicircle in the retracted pharynx. The initial or larval maxillae are different from the juvenile and adult ones. They have been described for several species of Onuphidae. Shed larval maxillae have been found in the gut of juveniles, attesting to their replacement by juvenile maxillae (Hsieh and Simon, 1987). The only report of a specimen undergoing adult maxillary replacement is by Ehlers (1868), who saw a Eunice harassii Audouin and Milne Edwards, 1833 with fully formed jaws that were soft and white. He concluded that the animal was moulting its jaws; the old jaw was lost and the new one was not sclerotized yet.
In the mid seventies I was engaged in a study of the Australian beachworms (Paxton, 1979), where I examined more than 500 specimens from juveniles to large adults and never encountered any maxillae that appeared to be in the process of replacement. This total lack of evidence and the apparent addition of new teeth to the distal parts of maxillae led me to propose that maxillae grow throughout the life of the worm (Paxton, 1980). This hypothesis has been contradicted by Colbath (1987) who showed that the internal maxillary jaws are inconsistent with continuous maxillary growth. In his study of paulinitid scolecodonts from Gotland, Bergman (1989) discussed moulting of jaws and came to the conclusion that 'it is reasonable to assume that the jaws of many Lower Palaeozoic eunicids were shed and replaced during growth.'

The fortuitous preservation of several young specimens of the onuphid Diopatra aciculata Knox and Cameron, 1971, during the process of moulting, allowed the study of different stages of the maxillary moult and enabled me to confirm Ehlers' observation. The process of moulting in D. aciculata was briefly described elsewhere, to explore some possible implications for the question of the symplesiomorphic or homoplasic status of ecdysis in annelids and ecdysozoans (Paxton, 2005). The aim of the present paper is to describe the replacement or moulting of adult maxillary jaws in Diopatra aciculata as an example of the Labidognatha and to compare it to the state of knowledge of the other evolutionary grades of Eunicida.

\section{MATERIALS AND METHODS}

Diopatra aciculata are reared in outside ponds at an aquaculture facility near Lake Macquarie, New South Wales, Australia. Among routinely collected and preserved specimens I discovered five specimens in various stages of moulting. At the time of collection (1 May 2003) these worms were 82 days old. They were preserved in $10 \%$ formalin and later transferred to $70 \%$ ethyl alcohol. The specimens measured $25-57 \mathrm{~mm}$ in length (75-109 chaetigers) and $2.0-3.5 \mathrm{~mm}$ in width at chaetiger 10 . The maxillary apparatuses were dissected and examined/ drawn/photographed as temporary slide preparations mounted in diluted glycerine. The specimens are deposited at the Australian Museum, Sydney (AM W. 29262-29265). 


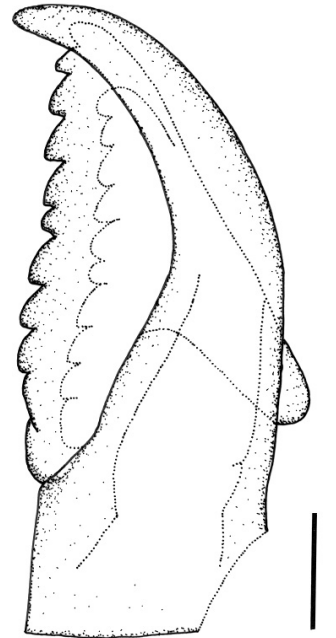

FIG. 1. - Diopatra aciculata (AM W. 29262). Right pharate maxillae I and II. Scale bar $=200 \mu \mathrm{m}$.
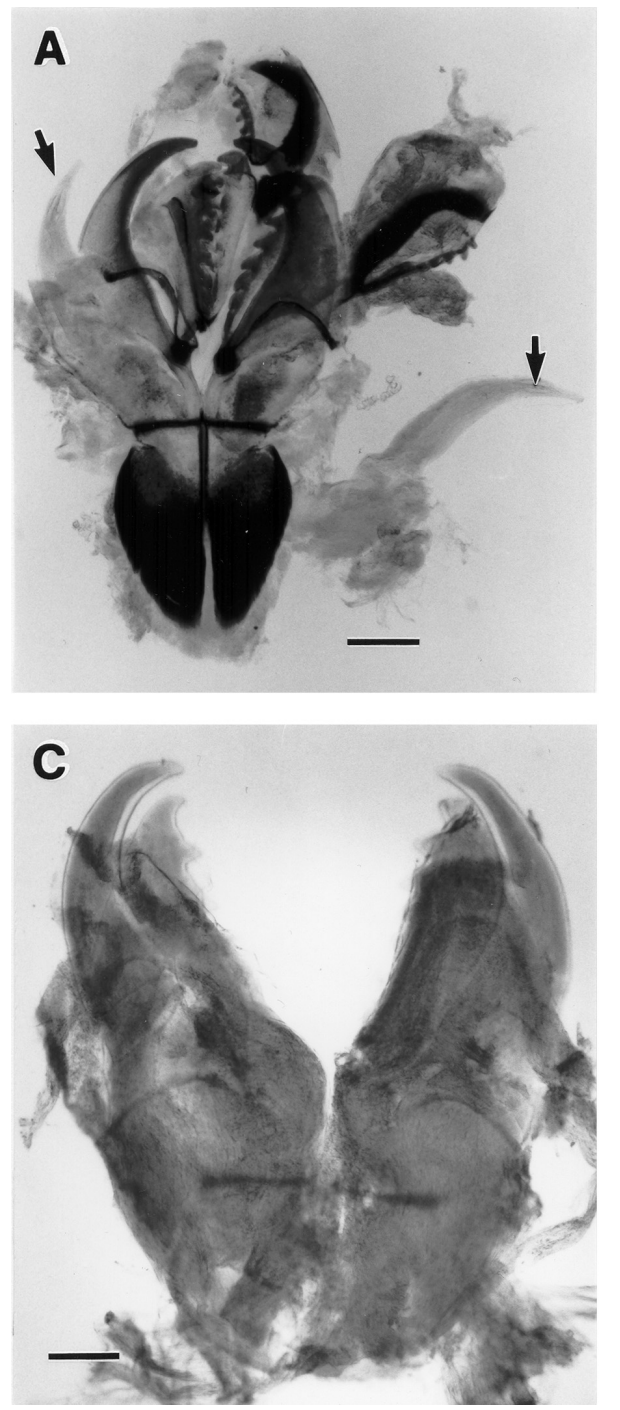

\section{RESULTS}

Moulting of the adult labidognath maxillary apparatus was observed in five specimens of D. aciculata and the different stages are described below.

Retraction of epidermal cells from inner surface of old jaw: In lightly sclerotized maxillae one can occasionally see what looks like a jaw within the jaw. The epidermal cells of the jaw have withdrawn from the inner surface of the old cuticle. In cases where the retraction is in a progressed state one can make out the new cuticle (Fig. 1). It is interesting to note that the new jaw is a faithful copy of the old one. In the specimen figured, the number of teeth in the new jaw is the same as in the old jaw. Even the shape of the teeth is the same as can be seen in the
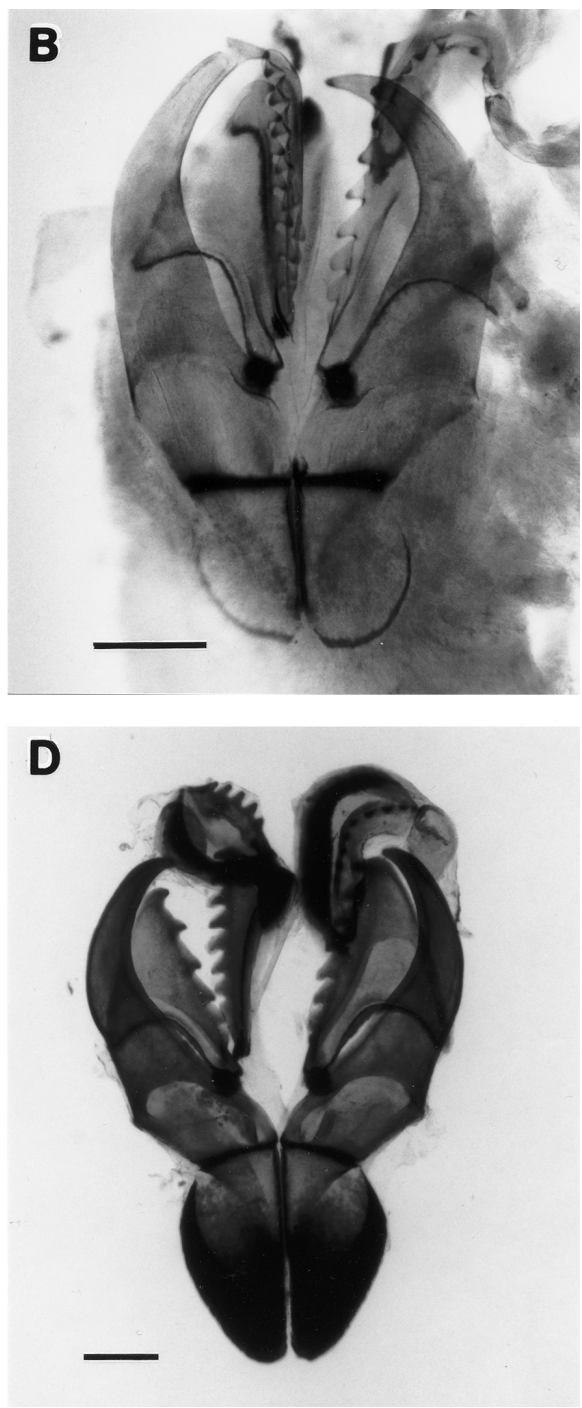

FIG. 2. - Diopatra aciculata. A, maxillary apparatus in process of shedding, displaying old and new maxillae I, arrows point to new maxillae I; B, recently moulted maxillary apparatus; C, newly moulted maxillary apparatus (anterior maxillae removed); D, shed old cuticle of specimen in previous figure, note difference in size. (A, AM W. 29263; B, AM W.29264; C, D AM W. 29265. Scale bars = 200 $\mu$ m). 
fifth and sixth tooth of maxilla II which are unusually close together in the old jaw and they are identically formed in the new one.

Shedding of old jaw: In an old jaw that is still in place but ready to be shed, the anterior maxillae appear somewhat loose. During the dissection of one maxillary apparatus, the old cuticle of the anterior maxillae IV and V separated from the new maxillae and was followed by maxillae II and III. As I was holding on to the freed new jaw apparatus the new forceps-like maxillae I were pulled through the cavity openings of the old jaw. The result of this facilitated partial shedding is a maxillary apparatus that displays both the old and new maxillary plates. The old carrier is still in place, but both the new unsclerotized maxilla I and the old sclerotized maxilla I now devoid of living tissue appear attached to it (Fig. 2A).

Recently moulted jaws: A recently moulted jaw found in situ, was dissected, and is shown as Figure 2B. It is overall lightly sclerotized, of a very light brown colour. The darkest sclerotization can be seen at the articulation between the carriers and maxillae I, and the attachment between maxillae I and II. The other darkened areas are the median fusion of the carriers, the basal margins of the carriers, the basal margins of maxillae II and III, and the tips of the individual teeth.

In one specimen a newly moulted jaw was discovered in situ. The maxillary apparatus was displaying the fully formed jaw, but it was white and soft. After dissection it is shown here as Figure 2C. The anterior maxillae were removed to prevent obstruction of maxillae I and II. The jaws are almost totally white, except for the articulation between the carriers and maxillae I, and the margin of the inner pulp cavity of maxillae I. Examination of the gut content of this specimen revealed one fecal pellet that appeared to contain a sclerotized structure. Upon careful extrication this was found to be a completely articulated maxillary apparatus that had been folded lengthwise and was encased in mucus (Fig. 2D). The individual elements are in perfect condition, even the forcepslike maxillae I, indicating that shedding occurred without splitting of the old jaw. The new unsclerotized jaw (Fig. 2C) is appreciably larger than the old shed jaw (Fig. 2D). The length of the right maxilla I measures $233 \mu \mathrm{m}$ in the former and 168 $\mu \mathrm{m}$ in the latter, showing that the new jaw is 1.4 times as long as the old one.

\section{DISCUSSION}

The process of moulting of the labidognath adult maxillary apparatus of $D$. aciculata proceeds most likely in a fashion similar to arthropod moulting, where it is defined as the periodical formation of new cuticle of greater surface area and shedding of the old cuticle (Gullan and Cranston, 1994). It is initiated by apolysis, where the epidermal cells retract from the inner surface of the old cuticle. Then new cuticle is laid down by the epidermal cells, giving rise to the state that is known for insects as the 'cloaked' or pharate phase, within the cuticle of the previous instar (Gullan and Cranston, 1994). In lightly sclerotized jaws, this can sometimes be observed in the moulting jaw (Fig. 1). In arthropods the inner part of the old cuticle is resorbed which may also occur in the labidognath maxillae.

Ecdysis is the shedding of the entire old arthropod cuticle. However, in D. aciculata it is only the old cuticle covering the jaw area that is shed. It is separated already from the underlying tissues, but must separate also somehow from the surrounding cuticle. After this it lifts off the most anterior maxillae and their attachment lamellae, to be followed with maxillae III, II and I. A particularly important find was the recovery of the shed maxillary apparatus from the gut of a newly moulted specimen (Fig. $2 \mathrm{C}, \mathrm{D})$. The undamaged apparatus shows that it can be shed even from the forceps-like maxillae I without having to split like insect exoskeletons. The maxillary apparatus is shed as a single structure with the individual maxillary elements connected to each other and with the clear cuticle covering the areas between maxillary elements. It is surprising that the new long and slender maxillae I can extricate themselves from the old jaw through the relatively small pulp cavity. Mierzejewski (1978) discussed the possibility of moulting jaws in other fossil Eunicida besides the placognath forms. He came to the conclusion that moulting of the anterior elements of the labidognath apparatus could occur but that 'the possibility of forming pharate jaws by elements having partly covered myocoeles is rather improbable.

After the old cuticle, or exuviae as it is termed in arthropods (Gullan and Cranston, 1994) is shed, the new jaw is probably expanded by fluids, and the new cuticle becomes sclerotized by chemical hardening and darkening, which is referred to as tanning. During this time the worms are in a vulnerable state. Because of the almost complete absence of newly 
moulted worms, it must be assumed that the jaws are functioning again in a rather short time and that the intervening time is spent in hiding.

The carriers of a newly moulted maxillary apparatus of $D$. aciculata are short and heart-shaped with only the basal margins sclerotized (Fig. 2B, C). Recently shed carriers, however, are considerably basally lengthened and very dark (Fig. 2A, D). This postmoult lengthening of the carriers is growth by apposition, proceeding at the expense of the adjacent pharyngeal cuticle. It should be interesting to investigate whether this also happens in other species. If that proves to be the case, it would further reduce the value of jaws as a taxonomic help for species identification.

The difference in size between two instars in insects is called the moult increment. The increase of sclerotized parts, such as the head capsule, in a regular, linear progression in successive instars, is known as Dyar's rule (Gullan and Cranston, 1994). The length of the new maxilla I (Fig. 2C) over that of the old maxilla I (Fig. 2D) equals 1.4 and represents the moult increment. This value agrees with the usual insect moult increment of about 1.4 (Hinton and Mackerras, 1970). Knowing the moult increment for a given species will allow one to calculate how many times an individual has replaced its maxillary apparatus. However, before this information can be of any benefit for population studies, we need to know whether there is any periodicity to moulting.

Maxillary moulting as described for D. aciculata is expected to occur in all extinct and extant Labidognatha. The extant Onuphidae and Eunicidae are regarded as closely related on the basis of their morphology (Hartman, 1944; Fauchald and Rouse, 1997), which has been corroborated by genetic studies (Struck et al., 2002; Hall et al., 2004). Their maxillae have only a thin outer layer of scleroprotein and are mineralized by a thick internal layer of aragonite (Colbath, 1986). However, the Lumbrineridae maxillae are mineralized with calcites (Colbath, 1986). Although the lumbrinerids have short carriers as typical for Labidognatha, the maxillary plates are in parallel rows. Orensanz (1990) regarded their arrangement as sub-prionognath to labidognath. The structure of the lumbrinerid mandibles also differs from those of onuphids and eunicids in being more or less fused along the symphysis (Orensanz, 1990). Although the three families were considered to be closely related (Hartman
1944; Kielan-Jaworowska, 1966), genetic studies have placed the Eunicida into two major clades, with the Lumbrineridae separated from the Eunicidae and Onuphidae (Struck et al., 2002). Future comparative studies of jaw types may remove the Lumbrineridae from the Labidognatha. Even though the lumbrinerid maxillae are mineralized by calcite rather than aragonite, they are covered by a thin layer of scleroprotein like eunicids and onuphids, and the internal canals of each tooth of the maxillary plates are equally visible with light microscopy (personal observation). Although moulting has not been observed, it is expected to occur in a similar fashion as described for D. aciculata.

The extinct Eunicida with placognath jaws also underwent a moulting process as is evidenced by the occasional finds of pharate jaws. For the pharate jaw to form, apolysis must have occurred and been followed by the formation of the new jaw. It can only be speculated as to why the customary ecdysis or shedding of the old jaw did not take place. The problem is confounded by the fact that polypharate jaws with up to eight interlocked jaws have been found. Mierzejewski (1978) discussed this and came to the conclusion that the moulting of placognath jaws was a typical phenomenon of a cyclic physiological regeneration rather than a reparative regeneration, and was not necessarily connected with their growth. It seems reasonable that the placognath jaws moulted in a similar process to that described here for $D$. aciculata to accommodate their growth, and that specimens recovered as the single pharate jaw died during moulting. Mierzejewski (1978) thought that the possibility of the death of an organism in the pharate state is rather small. However, many insects spend a substantial period in the pharate state waiting for favourable conditions for emergence and this might also apply for the emergence of the new polychaete jaws. Particularly if sclerotization of the new jaws is a slow process and prevents the worm from carrying out its normal activities for some time, they may delay ecdysis under certain conditions. However, I can see no advantage in having polypharate jaws and can only conclude that it must be the result of a process gone wrong.

Two incompletely developed maxillary apparatuses of extant Prionognatha have been interpreted as evidence of jaw replacement (KielanJaworowska, 1966; Colbath, 1987). In the moulting process of D. aciculata there is no stage where the jaw appears incompletely developed since the new 
jaw develops hidden in the pulp cavity. The two reports are either describing abnormal jaws, or jaw replacement in the Prionognatha proceeds by a different process, where the old jaws are shed before the new ones develop. Prionognath jaws are heavily sclerotized like the ctenognaths. In the Ctenognatha the replacement jaws develop in epithelial sac-like structures ventrolateral to the existing jaws. Because of this position, both sets of jaws are visible (Paxton, 2004). On this basis we can rule out the possibility that the prionognaths replace their maxillae in the same manner, since only the partially formed jaws were visible in the two prionognath specimens.

In considering jaw replacement or moulting in Eunicida, it appears probable that the ctenognath method of maxillary replacement is limited to this group. Not enough is known about Prionognatha, although shedding before replacement may take place. In Labidognatha the maxillae undergo apolysis and ecdysis similar to arthropods. Although the Lumbrineridae maxillae may not really be of the labidognath type, they are expected to moult by the same process. This type of moulting most likely also occurred in the extinct Placognatha as is evidenced by occasional finds of jaw-in-jaw specimens.

\section{ACKNOWLEDGEMENTS}

I am grateful to Milada Safarik and Aquabait Pty. Ltd. for provision of study material and to Ron Oldfield, Microscopy Unit, for photography.

\section{REFERENCES}

Bergman, C.F. - 1989. Silurian paulinitid polychaetes from Gotland. Fossils and Strata, 25: 1-128.

Colbath, G.K. - 1986. Jaw mineralogy in eunicean polychaetes
(Annelida). Micropaleont., 32: 186-189.

Colbath, G.K. - 1987. Evidence for shedding of maxillary jaws in eunicoid polychaetes. J. Nat. Hist., 21: 443-447.

Ehlers, E. - 1868. Die Borstenwürmer (Annelida Chaetopoda) nach systematischen und anatomischen Untersuchungen dargestellt. Abt. II, pp. 269-748. Engelmann, Leipzig.

Fauchald, K. and G. Rouse. - 1997. Polychaeta systematics: past and present. Zool. Scr., 26: 71-138.

Gullan, P.J. and P.S. Cranston. - 1994. The Insects: an Outline of Entomology. Chapman and Hall, London.

Hall, K.A., P.A. Hutchings and D.J. Colgan. - 2004. Further phylogenetic studies of the Polychaeta using 18S rDNA sequence data. J. Mar. Biol. Ass. U.K., 84: 949-960.

Hartman, O. - 1994. Polychaetous annelids. Part 5. Eunicea. Allan Hancock Pac. Exped., 10: 1-238.

Hinton, H.E. and I.M. Mackerras. - 1970. Reproduction and Metamorphosis. In: The Insects of Australia, pp. 83-106. CSIRO, Melbourne University Press, Carlton.

Hsieh, H.-L. and J.L. Simon. - 1987. Larval development of Kinbergonuphis simoni, with a summary of development patterns in the family Onuphidae (Polychaeta). Proc. Biol. Soc. Wash., 7: 194-210.

Kielan-Jaworowska, Z. - 1966. Polychaete jaw apparatuses from the Ordovician and Silurian of Poland and a comparison with modern forms. Pal. Polonica, 16: 1-152.

Mierzejewski, P. - 1978. Molting of the jaws of the early paleozoic Eunicida (Annelida, Polychaeta). Acta Pal. Polonica., 23: 73-88.

Orensanz, J.M. - 1990. The eunicemorph polychaete annelids from Antarctic and Subantarctic seas. With addenda to the Eunicemorpha of Argentina, Chile, New Zealand, Australia, and the southern Indian Ocean. In: L.S. Kornicker (ed.), Biology of the Antarctic seas 21, Antarctic Research Series 52, pp. 1-183. American Geophysical Union, Washington, DC.

Paxton, H. - 1979. Taxonomy and aspects of the life history of Australian beachworms (Polychaeta: Onuphidae). Aust. J. Mar. Freshw. Res., 30: 265-294.

Paxton, H. - 1980. Jaw growth and replacement in Polychaeta. $J$. Nat. Hist., 14: 543-546.

Paxton, H. - 2000. Eunicida. In: P.L. Beesley, G.J.B. Ross and C.J. Glasby (eds.), Polychaetes and allies: the southern synthesis. Vol. 4A: Polychaeta, Myzostomida, Pogonophora, Echiura, Sipuncula, pp. 89-106. CSIRO Publishing, Melbourne.

Paxton, H. - 2004. Jaw growth and replacement in Ophryotrocha labronica (Polychaeta, Dorvilleidae). Zoomorphology, 123: $147-154$.

Paxton, H. - 2005. Molting polychaete jaws - ecdysozoans are not the only molting animals. Evol. Dev., 7: 337-340.

Szaniawski, H. - 1996. Chapter 12. Scolecodonts. In: J. Jansonius and D.C. McGregor (eds.), Palynology: principles and applications. Vol. 1, pp. 337-354. American Association of Stratigraphic Palynologists Foundation.

Struck, T.H., W. Westheide and G. Purschke. - 2002. Progenesis in Eunicida ("Polychaeta," Annelida) - separate evolutionary events? Evidence from molecular data. Molec. Phylogen. Evol., 25: 190-199.

Received September 13, 2004. Accepted May 11, 2005. 